\begin{tabular}{|c|c|}
\hline 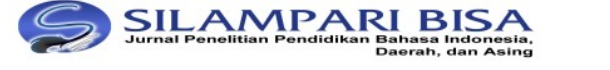 & $\begin{array}{l}\text { PRINTED ISSN: 2620-6919 } \\
\text { ONLINE ISSN: 2620-3316 }\end{array}$ \\
\hline $\begin{array}{l}\text { Published by LP4MK STKIP PGRI LUBUKLINGGAU } \\
\text { Prodi Pendidikan Bahasa Indonesia, STKIP PGRI Lubuklinggau, } \\
\text { South Sumatera, Indonesia }\end{array}$ & $\begin{array}{r}\text { Vol. 3, No. 2, } 2020 \\
\text { Page: } 428-439\end{array}$ \\
\hline
\end{tabular}

\title{
STUDENTS' PERCEPTION ON ONLINE ENGLISH LEARNING DURING COVID-19 PANDEMIC ERA
}

\author{
Lisa Rakhmanina ${ }^{1 *}$, Feny Martina ${ }^{2}$, Friang Br Halolo ${ }^{3}$, Syafryadin ${ }^{4}$, Noermanzah $^{5}$ \\ ${ }^{1,3}$ English Education Study Program, Teacher Training and Education Faculty \\ University of Prof. Dr. Hazairin, SH., Bengkulu \\ ${ }^{2}$ Tadris Bahasa Inggris, IAIN Bengkulu \\ ${ }^{4,5}$ Department of Language and Arts Education, Universitas Bengkulu \\ Email: lisarakhmanina83@gmail.com ${ }^{* 1}$, feny@iainbengkulu.ac.id ${ }^{2}$, \\ frianghalolo21@gmail.com ${ }^{3}$, syafryadin@unib.ac.id ${ }^{4}$, noermanzah@unib.ac.id ${ }^{5}$
}

\begin{abstract}
The Covid-19 pandemic has caused schools and universities to close so that online learning is one of the solutions to prevent the spread of the Covid-19 virus. This study aims to describe students' perceptions of learning English online during the Covid-19 pandemic. This research used descriptive quantitative method. The subjects analyzed consisted of two different department groups at University of Prof. Dr. Hazairin, SH. in the 2019/2020 academic year. The number of respondents was 66 participants. The data collection technique in this study used a questionnaire distributed in the form of a Google form regarding student perceptions of the application of online English learning. The results of this study indicate that most students are interested in online learning. Online learning is considered to be more fun and flexible. In terms of the platform that is the medium for implementing online learning itself, the WhatsApp application is considered the best or dominant application and is very helpful for online learning during the pandemic. Therefore, this data proves that the research respondents had positive perceptions of online learning during the Covid-19 pandemic.
\end{abstract}

Keywords: perception of students, online learning, Covid-19 pandemic

\section{PERSEPSI MAHASISWA TENTANG PEMBELAJARAN BAHASA INGGRIS SECARA DARING SELAMA ERA PANDEMI COVID-19}

\begin{abstract}
Abstrak
Pandemi Covid-19 telah menyebabkan sekolah dan universitas tutup sehingga dilakukan pembelajaran dalam jaringan (daring) menjadi salah satu solusi untuk mencegah penyebaran virus Covid-19. Penelitian ini bertujuan untuk mendeskripsikan persepsi mahasiswa terhadap pembelajaran bahasa Inggris secara daring pada masa pandemi Covid-19. Penelitian ini menggunakan metode deskriptif kuantitatif. Subjek yang dianalisis terdiri dari dua kelompok jurusan yang berbeda di Universitas Prof. Dr. Hazairin, SH. pada tahun akademik 2019/2020. Jumlah responden sebanyak 66 partisipan. Teknik pengumpulan data pada penelitian ini menggunakan angket yang didistribusikan dalam bentuk formulir Google tentang persepsi mahasiswa terhadap penerapan pembelajaran bahasa Inggris secara daring. Hasil penelitian ini menunjukkan bahwa sebagian besar mahasiswa tertarik dengan pembelajaran daring. Pembelajaran daring dianggap lebih
\end{abstract}


Lisa Rakhmanina, Feny Martina, Friang Br Halolo, Syafryadin, Noermanzah
Students' Perception on Online English Learning during Covid-19 Pandemic Era

menyenangkan dan fleksibel. Dalam hal platform yang menjadi media terlaksananya pembelajaran daring itu sendiri, aplikasi WhatsApp dianggap aplikasi yang terbaik atau dominan dan sangat membantu pembelajaran daring pada masa pandemi. Oleh karena itu, data ini membuktikan bahwa responden penelitian telah memiliki persepsi positif terhadap pembelajaran daring di masa pandemic Covid-19.

Kata kunci: persepsi siswa, pembelajaran daring, pandemi Covid-19

\section{A. Introduction}

Recently numerous countries around the world have been surprised by the corona or Covid-19 outbreaks. This crisis is taking place everywhere. The situation around the world has changed drastically. As a result of the spread of this virus, several industries have undergone a crisis. It was not just the economic sector that was affected, but also the education sector. Most of the governments worldwide have shut down the educational institutes to avoid the infection of Covid-19. This has been recognized by the United Nations Education, Scientific and Cultural Organization (UNESCO) on Thursday (5/3), that Corona virus outbreak has impacted the education sector. In December 2020, the number of confirmed COVID-19 cases in Indonesia has reached more than 91.602 cases (Kompas, 2020). The Ministry of Education in Indonesia has introduced a plan aimed at dismantling educational institutions and replacing the teaching and learning process (KBM) with online systems. The online teaching is the choice of many nations throughout Indonesia especially in Bengkulu, both at primary and university level. The global spread of the COVID-19 pandemic triggers class suspensions that result in online learning needs (Moorhouse, 2020).

Nadiem Makarim, the Indonesian Minister of Education and Culture, also suggested that teachers use various e-learning platforms, such as Rumah Belajar, WhatsApp, Quipper School, Ruang Guru, Google Meet, Google Classroom, Zoom, and so on (Azwandi, et al. 2019; Putsanra, 2020; Anggitasari, et al. 2020; Syahrial \& Syafryadin, 2020). These online learning platforms are now popular in Indonesia since they are used and installed widely. In Turkish, applications like Teams and Zoom have been commonly used. Google Classroom is also very famous in Iraq since the study material in Iraq was uploaded in the Google classroom. Google Classroom allows students to quickly identify and research content on their topics (Sukmawati \& Nensia, 2019; Marharjono, 2020). In short, the use of platforms 
during the pandemic is needed to facilitate the teacher delivering the material to students.

Universitas Prof Dr. Hazairin SH, as one of the Universities in Bengkulu, was very responsive in reacting to this pandemic and took steps to prevent the transmission of COVID-19 by eliminating campus activities in the middle of the pandemic. In addition, the concept of social distancing, and physical distancing requires everyone to stay home so that the spread of this virus is not expanding (Deli \& Allo, 2020). On almost all educational stages, changing face-to-face experiences of the teaching and learning process then performed through online learning is applied. This learning practice is called PJJ (Distance Education) in schools, while it is known as e-learning or online learning at universities.

In terms of analyzing perception, it is important to define this term first. Perception is the object, occurrence, and relationship experience acquired by resuming and interpreting message knowledge. In resuming information and predicting message, it gives a sense to stimulus-response that includes focus, hope, motivation, and memory. Michotte (2019) \& Septinawati, et al. (2020) then establishes perception as a step of the total action process that helps us to adapt our behavior to the environment we live in. Martono (2010) also stated that perception is a way of looking at a problem that occurs or a particular point of view used in seeing a phenomena. Therefore, in this study, the experience of the students focuses on the students' participation, language difficulties levels, internet issues, and also an online learning platform suitable to their needs and condition. These variables are important to make the understanding of online learning by students more contextual to the needs of this study.

In terms of online learning, this term is described as learning from a distance. Stern (2018) stated that online learning is just a form of 'distance learning', the umbrella term for any distance learning that takes place rather than conventional classroom learning. Electronic devices, such as tablets, smartphones, laptops and computers that need internet connectivity, are supported (Gonzalez \& Louis, 2018). Aparicio, Bacao, \& Oliveira (2016), which offers the scope of online learning, divides online learning into two main areas, learning, and technology, 
where learning is the cognitive mechanism for knowledge achievement, and technology is the tool to help the process of knowledge achievement. With the Information and Technology case, some of us are innovating to shape IT that can be personalized to make it easier for others to carry out day-to-day activities, beginning with messages of causation, assignments and on-line contact, exploring and acquiring a few items online, ordering tickets and modes of transport on-line and many others. Khusniyah \& Hakim (2013) shows that many of ICT's education potential edges are, acting as a collaborator for long-term learning, making improvements in the role of the teacher in teaching and hence in the role of scholars in learning, open access for interactive materials and data across networks, and removing time and scope constraints within the learning environment.

Therefore, when the outbreak of Covid-19 forced all schools to close and students to study from home, they were hardly faced with the problem of adaptation. In addition, the role of educators is very critical for successful online learning to be carried out. To participate in an online classroom, certain competencies are required. Skills such as communication skills, technical competence, insightful input provision, administrative skills, accessibility, learning monitoring and student support are required (Kusmiarti et. al., 2020). The quality of education can also be enhanced by access to technology, but not all educators have the maximum skills necessary for online teaching. This sometimes becomes a disparity between students and teachers, and so the technical skill of all educators must continue to be improved.

\section{B. Research Methodology}

This study applied quantitative descriptive by relying on the survey to provide a valuable analytical study on the subject or relevant issue from a number of individuals. As a sample, there were 66 students from the two study programs: Guide and Counseling and Agro technology in academic year of 2019/2020. The researcher used purposive sampling involving a number of students who had a strong network to access online learning during Covid-19 pandemic. 
The study method was a questionnaire obtained via Google Form and depth interview. The questionnaire was used to collect sample data to describe the perspective of using online learning. The questionnaire consisted of 30 items as open-ended questionnaires. The research data were obtained by Google form by analyzing respondents of participants to understand their perspective of using online learning to obtain the necessary information, then data were analyzed and described to obtain answers to questions. The questionnaire metrics are composed of four indicators: 1) student's participation, 2) language difficulties levels, 3) internet issues, and 4) online learning platform suited with their needs and condition.

\section{Results and Discussion}

\section{Results}

The results of the study were collected from 66 students from Guide and Counseling Major and Agro technology Major respondents. The findings from the questionnaire are presented in further explanation.

a. Student's Participation

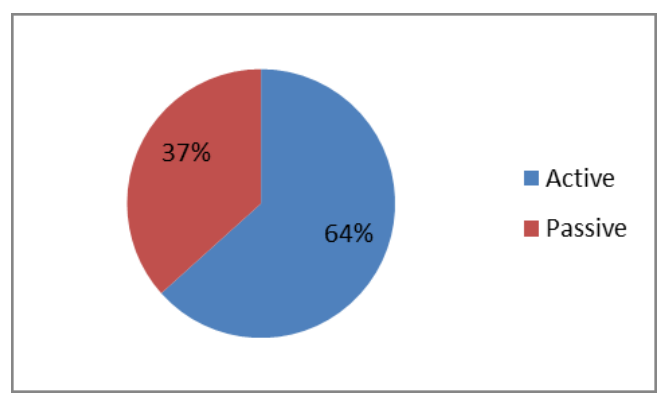

Figure 1. The Percentage of Student's Participation

Figure 1 shows the response and participation of learners about learning English online. Among the sixty-six students who participated in online session, 64 $\%$ of respondents responded actively during online session. Meanwhile, $36 \%$ of respondents reacted passively as they don't have enough data or quota and no proper gadget to support their learning. In the least developed region, poor conditions were common because of its limited infrastructure and public facilities (Agung, 2019). 
Lisa Rakhmanina, Feny Martina, Friang Br Halolo, Syafryadin, Noermanzah
Students' Perception on Online English Learning during Covid-19 Pandemic Era

b. Students' Comprehension of Language Skills

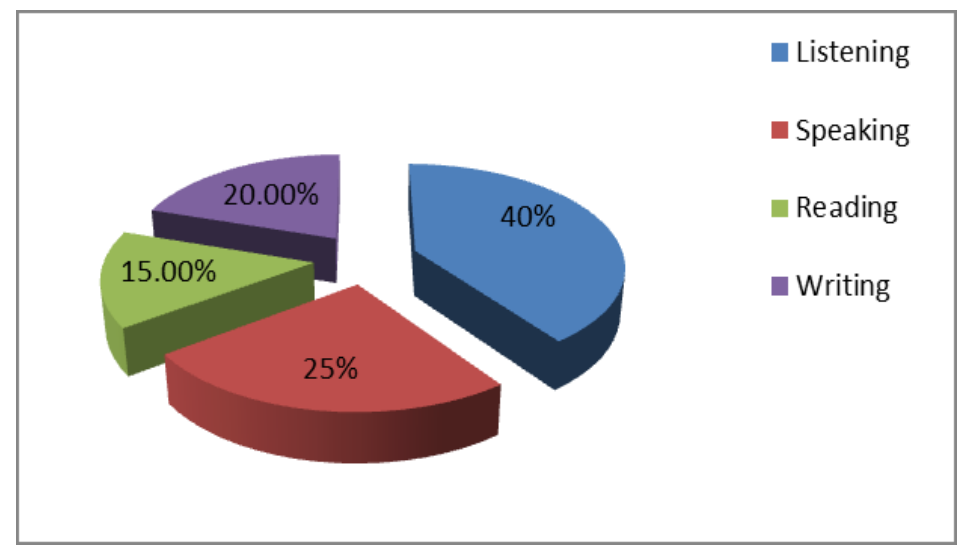

Figure 2. The Percentage of Students' Comprehension of Language Skills

This figure reflects the learners' comprehension of the level of language skills they had to learn in online English. In this questionnaire, there are four skills to be measured such as Listening, Speaking, Reading and writing. Respondents were asked what skills are difficult to learn in the online English class, after measuring the percentage of responses, it is found that listening is the most difficult skill to learn in the online English class (40\%) and the second level of difficulty is speaking which gets $25 \%$ and then Writing (20\%) and the last one is Reading $(15 \%)$. It is in line with Alberth (2011) that student and teacher characteristics, instructional design, support for teachers and students, technology and language skills characteristics need to be carefully considered when planning online language learning simply because they could potentially affect the learning and learning experiences of students in this new learning environment.

c. Internet Issues

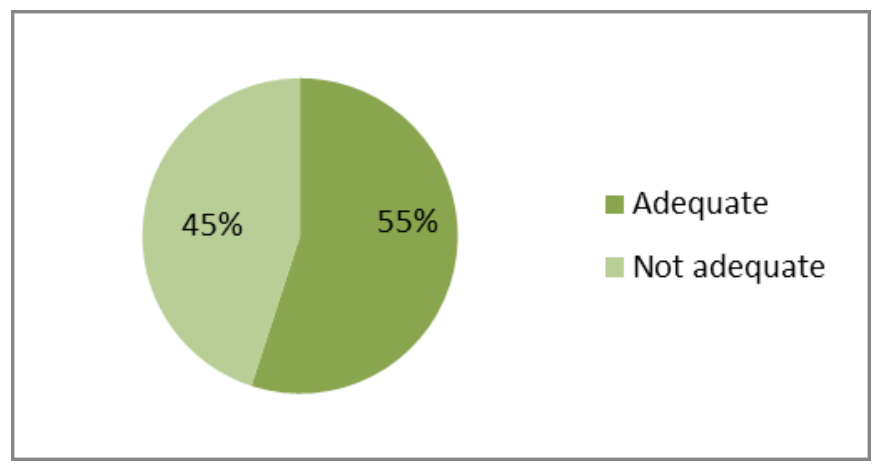

Figure 3. The Percentage of Internet Issues

Silampari Bisa: Jurnal Penelitian Pendidikan Bahasa Indonesia, Daerah, dan Asing Vol. 3, No. 2, 2020 
Figure 3 shows that $55 \%$ of respondents indicated that internet connectivity during online learning was adequate, while $45 \%$ of respondents claimed that internet access was not adequate for online learning.

d. Online Learning Platform

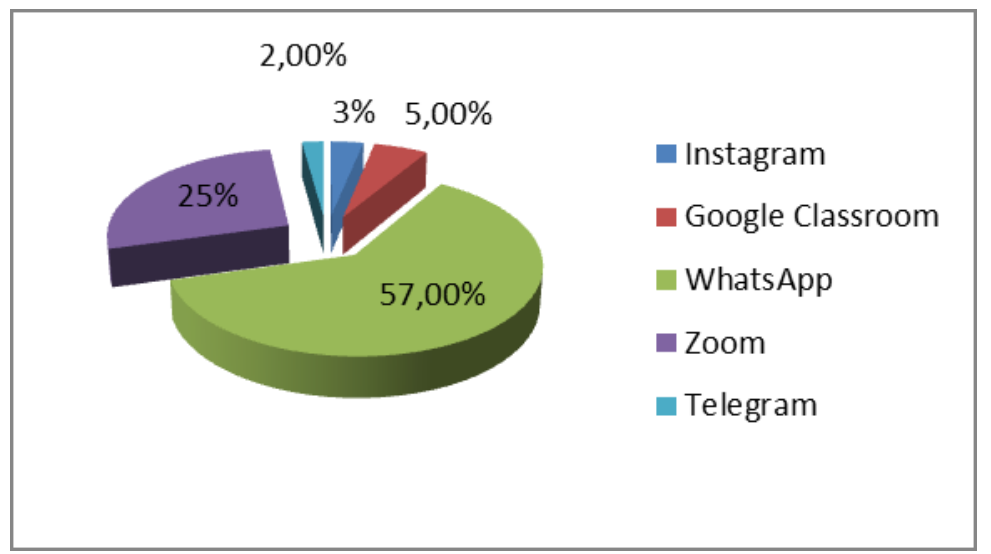

Figure 4. The Percentage of Online Learning Platform Used

According to the students, there are some types of online learning platforms for their home study, including Google Classroom, WhatsApp, Zoom,Telegram and Instagram. Not all of them were, however, suited to the student's situation and needs. The student recommendation on the use of the e-learning platform was 57 $\%$ on WhatsApp, $25 \%$ on Zoom, $5 \%$ for Google Classroom and $3 \%$ for Telegram and the last one is $2 \%$ on Instagram.

\section{Discussion}

\section{a. Students' Perception}

Revealing the outcome of the engagement of students, the data reveals that most students were actively engaged in online learning. It did not, however, imply that they were enthusiastic. Many students indicated that they were burdened by the tasks. In the meantime the students believed the meeting to be enjoyable, but were unable to stand up to the marathons task. During this pandemic, online learning was considered enjoyable to teach and to pay for learning. However the abundance tasks were killing them, since all the lecturers gave the task to them (Khusniyah \& Hakim, 2019). 
b. Students' Comprehension of Language Skills

From the findings shown in Figure 2, it is shown that listening skills are the most difficult skills to learn in online learning. The delivery of materials in online learning was relatively good. However, some students said that they needed much time in downloading the listening material because of the internet quality that they had. Others also revealed that they needed to find a quiet place to listen up and concentrate in answering the listening task while their circumstance was so noisy around (Le \& Pham, 2020). They also found it difficult to get the material because of their gadget didn't support the technology. In speaking, the students felt shy and not familiar to perform in the front of the screen in participating the role play, short talk, and others.

\section{c. Internet Issues}

The internet is considered to be the source of the necessary materials to achieve teaching and learning objectives (Surtikanti, 2020). During COVID-19, the need for internet is very high for learners; to engage in the online classroom, to search for information, to do assignments, and so forth. However, some regions with poor internet signals may have many problems with online learning. The figure 2 shows the result that $58.3 \%$ of respondents answered that internet access is adequate during online learning, meanwhile, $41.7 \%$ respondents said that internet access is not adequate for online learning. The issues of internet problems among learners are such as limited internet credit, slow internet network, or incompatible gadget or device. In this situation, the affordable and accessible connectivity of the internet is very helpful for learners. The Internet connection was the main issue of this condition. Network interaction can also present significant challenges for both teachers and students.

\section{d. Online Learning Platform}

WhatsApp was considered a friendly and familiar application for them and their devices with regard to the online learning platform that relevant for the requirements and situation of the students. Teaching materials (text, video, audio, 
learning connection, file, and photo) could be easily shared in two-way interactions via the WhatsApp community. In addition, the students argued that WhatsApp performed relatively well under a weak signal while the other apps did not perform as well as WhatsApp. Some respondent said that Zoom and Google classroom needed more data than Whatssapp (Noermanzah \& Suryadi, 2020; Fitriyani et al., 2020). Google Classroom, meanwhile, was relatively straightforward because it gave several options for accessibility (Khalil, 2018). Furthermore, the respondent indicated that Instagram and Telegram were not an interesting and appropriate platform for learning.

\section{Conclusion and Suggestions}

A large tide of paradigm shift in the Indonesian education system has been generated by the Covid-19 pandemic: from physical to online classroom. For the sake of human wellbeing, digital classrooms seem to be the right solution. Teachers and students are expected to work and study from home. Based on the findings above it can be inferred that students have a favorable outlook on online learning in the midst of the Covid-19 pandemic. Despite the issues and some challenges that they face, they consider online learning to be very beneficial, but not fully successful.

Another result is about the expectations of learners of the level of complexity of language skills they had to learn online learning in English. The students considered that the most challenging skill to learn in an online English class was the listening section. There is a very high need for the internet for learners; to engage in online classes, to look for information, to do tasks, and so on. In supporting the situation, affordable and open internet access is very important for learners. Teachers and schools should make attempts to respond to the needs of students, such as lack of financial support and accessibility of Internet connectivity. Furthermore, WhatsApp is highly recommended to be used before Zoom and others platforms because WhatsApp is more common to users (lecturers and students) and is easier to access Furthermore, this research highlights that the this study can become an input for lecturers and institutions in 
order to give more attention and enhance the standard of English online learning so that outcomes and results can be achieved as expected.

\section{References}

Agung, A.S.N. (2019). Current Challenges in Teaching English in Least-developed Region in Indonesia. SOSHUM: Jurnal Sosial dan Humaniora, 9(3), 266-271, http://dx.doi.org/10.31940/soshum.v9i3.1317.

Alberth. (2011). Critical Success Factors in Online Language Learning. TEFLIN Journal, 22(1). http://journal.teflin.org/index.php/journal/article/view/16

Anggitasari, M., Tarwana, W., Febriani, R. B., \& Syafryadin, S. (2020). Using Wattpad to Promote the Students' Responses to Literary Works: EFL College Students' Perspectives and Experiences of Enjoying Short Stories. Jadila: Journal of Development and Innovation in Language and Literature Education, 1(2), 182-192.

Aparicio, M., Bacao, F., \& Olivera, T. (2016). An E-Learning Theoretical Framework. Journal of Educational Technology Systems, 19(1), 292-307.

Azwandi, A., Harahap, A., \& Syafryadin, S. (2019). Penyuluhan dan Pelatihan IctEnhanced Teaching-Learning sebagai Model Pengembangan Profesional Guru di Kota Bengkulu. Jurnal Pengabdian Masyarakat IImu Terapan (JPMIT), 1(1).

Deli, M., \& Allo, G. (2020). Is the Online Learning Good in the Midst of Covid-19 Pandemic? The Case of EFL learners. Jurnal Sinestesia, 10(1), 1-10.

Fitriyani, F., Febriyeni, M. D., \& Kamsi, N. (2020). Penggunaan Aplikasi Zoom Cloud Meeting pada Proses Pembelajaran Online Sebagai Solusi di Masa Pandemi Covid 19. Edification Journal, 3(1), 23-34. doi:10.37092/ej.v3i1.221

Gonzalez, D., \& Louis, R. St. (2018). Online Learning. In J. I. Liontas (Ed.), The TESOL Encyclopedia of English Language Teaching (1st ed.). https://doi.org/10.1002/9781118784235.eelt0423

Khalil, Z. M. (2018). EFL Students' Perceptions towards Using Google Docs and Google Classroom as Online Collaborative Tools in Learning Grammar. Applied Linguistics Research Journal, 2(2), doi:10.14744/alrj.2018.47955

Khusniyah, N. L., \& Hakim, L. (2019). Efektivitas Pembelajaran Berbasis Daring: Sebuah Bukti pada Pembelajaran Bahasa Inggris. Jurnal Tatsqif, 17(1), 19-33. doi:10.20414/jtq.v17i1.667 
Kompas. (2020). Kasus Corona Indonesia 611.631, Ini 5 Provinsi dengan Kasus Tertinggi.https://www.kompas.com/tren/read/2020/12/13/124500065/kas us-corona-indonesia-611.631-ini-5-provinsi-dengan-kasustertinggi?page=all

Kusmiarti, R., Yuniati, I., \& Noermanzah. (2020). Improving Student Communication Skills In Learning Indonesian Language Through Collaborative Learning. Retrieved from osf.io/9km3u. International Journal of Scientific and Technology Research, 9(1).

Le, T. V., \& Pham, S. K. (2020). The Effects of Extensive Listening on Vietnamese Students' Listening Skills. Indonesian TESOL Journal, 2(1), 1-14. doi:10.24256/itj.v2i1.1246

Marharjono, M. (2020). Manfaat Pembelajaran Sejarah Menggunakan Google Classroom pada Masa Pandemi COVID-19. Ideguru: Jurnal Karya IImiah Guru, 5(1). doi:10.51169/ideguru.v5i1.155

Martono, N. (2010). Metode Penelitian Kuantitatif. Jakarta: Rajawali Pers.

Michotte, A. (2019). The Perception of Causality (1sted). London: Routledge.

Moorhouse, B. L. (2020). Adaptations to a Face-to-Face Initial Teacher Education Course "Forced" Online Due to the Covid-19 Pandemic. Journal of Education for Teaching, 46(4), 609-611. doi:10.1080/02607476.2020.1755205

Noermanzah, N. \& Suryadi, N. (2020). Improving Students Ability to Analyze Discourse Through the Moodle-Based Blended Learning Method. English Review: Journal of English Education, 9(1), 83. https://journal.uniku.ac.id/index.php/ERJEE/article/view/3781/0

Putsanra, D. V. (2020). Daftar E-Learning Kemendikbud, Sekolah Online untuk Mencegah Corona. https://tirto.id/daftar-e-learning-kemendikbudsekolah-online-untuk-mencegah-corona-eFrR.

Septinawati, S., Febriani, R.B., Tarwana, W., Syafryadin, S. (2020). Students' Perceptions Toward the Implementation of Quipper School as an ELearning Platform in Teaching English. Jadila: Journal of Development and Innovation in Language and Literature Education, 1(2), 223-238.

Stern, J. (2018). Introduction to Online Teaching and Learning. International Journal of Science Education, 3, 1-10. https://doi.org/10.1002/9781118784235.eeltv06b6 
Sukmawati, S., \& Nensia, N. (2019). The Role of Google Classroom in ELT. International Journal for Educational and Vocational Studies, 1(2), 142145. https://doi.org/10.29103/ijevs.v1i2.1526

Surtikanti, M. W. (2020). Textbook Evaluation on Curriculum 2013-Based Textbook "When English Rings A Bell" for the Seventh Grade. Journal of English Education and Literature, 1(1), 11-17.

Syahrial, S., \& Syafryadin, S. (2020). Pelatihan menjadi Guru Bahasa Inggris Kreatif dan Milenial di Sekolah Menengah Pertama Bengkulu Tengah. Jurnal Inovasi Pengabdian Masyarakat Pendidikan, 1(1). 18-35. 